\title{
Perhitungan Tingkat Kompetisi antar Murid atau Mahasiswa di Kelas dan Kaitannya Dengan Keadilan Guru atau Dosen Dalam Mengajar
}

\author{
Sigit Haryadi \\ Institut Teknologi Bandung \\ Pebruari 2018
}

DOI: $10.17605 / O S F .10 / A 894 W$

Haryadi, S. (2018, February 17). Perhitungan Tingkat Kompetisi antar Murid atau Mahasiswa di Kelas dan Kaitannya Dengan Keadilan Guru atau Dosen Dalam Mengajar. Retrieved from osf.io/a894w

\section{RINGKASAN}

Pada makalah ini, diusulkan suatu metoda pengukuran tingkat kompetisi antar murid atau mahasiswa yang terjadi di kelas dan kaitannya dengan tingkat keadilan guru atau dosen yang mengajar. Teknik pengukuran yang dilakukan adalah dengan menggunakan rumus yang dibuat pada bulan April 2016, oleh Sigit Haryadi, dan dinamakan sebagai “Indeks Haryadi”. Metoda ini sangat penting karena ada sebagian guru dan dosen yang mengajar di kelas yang tidak pernah melakukan introspeksi, apakah dia sudah adil terhadap murid-muridnya di kelas yang diajarnya, dimana guru atau dosen tersebut selalu beranggapan bahwa jika ada murid atau mahasiswa yang tidak bisa mengikuti pelajaran di kelas yang diajarnya, adalah dianggap sebagai kesalahan murid atau mahasiswa.

\section{Kalkulator Internet}

Untuk mempermudah perhitungan, telah dibuatkan suatu "kalkulator internet", yaitu suatu website yang menyediakan kolom isian, dimana seorang guru atau dosen dapat mengisikan nilai ujian dari murid atau mahasiswa yang diajarnya, lalu mendapatkan hasil perhitungan sebagai berikut: (a) indeks kompetisi antara murid atau mahasiswa di kelas, (b) Tingkat Kompetisi antar murid atau mahasiswa di kelas yang disertai dengan analisis terhadap situasi persaingan yang terjadi di kelas dengan tingkat keadilan guru atau dosen dalam mengajar di kelas.

Alamat website tersebut adalah: http://sigitharyadi.net/id/multidicipline/tingkat-kompetisimurid-atau-mahasiswa-di-kelas/ 


\section{Teknik Perhitungan Dan Analisis Terhadap Hasil Perhitungan}

Analisis terhadap hasil perhitungan tingkat kompetisi antar murid atau mahasiswa di kelas dengan menggunakan Indeks Haryadi adalah sebagai berikut:

I. Indeks lebih besar atau sama dengan 0,75 adalah menunjukkan adanya kompetisi antar murid atau mahasiswa di kelas yang seimbang, dan berarti bahwa kelas telah berjalan normal, dimana kemampuan murid atau mahasiswa di kelas menyerap pelajaran adalah relatif merata, dan terdapat indikasi bahwa guru atau dosen telah mengajar dengan adil

II. Indeks berada di antara 0,5 dan 0,75 menunjukkan adanya kompetisi antar murid atau mahasiswa di kelas yang kurang seimbang, dan berarti kelas telah berjalan kurang normal, dimana kemampuan murid atau mahasiswa menyerap pelajaran adalah relatif kurang merata yang mengindikasikan adanya kemungkinan bahwa guru atau dosen telah mengajar dengan agak kurang adil. Dalam hal ini, jika bisa dibuktikan terdapat fakta bahwa kesalahan ada di pihak murid atau mahasiswa, maka guru atau dosen bisa dibebaskan dari prasangka telah mengajar dengan agak kurang adil.

III. Indeks kurang dari 0,5 menunjukkan adanya kompetisi antar murid atau mahasiswa di kelas yang sangat tidak seimbang, dan berarti kelas telah berjalan tidak normal, dimana kemampuan murid atau mahasiswa menyerap pelajaran adalah sangat tidak merata yang mengindikasikan adanya kemungkinan bahwa guru atau dosen telah mengajar dengan tidak adil. Dalam hal ini, jika bisa dibuktikan terdapat fakta bahwa kesalahan ada di pihak murid atau mahasiswa, maka guru atau dosen bisa dibebaskan dari prasangka telah mengajar dengan tidak adil.

\section{Penjelasan cara perhitungan:}

1. Pertama, dihitung share dari nilai ujian setiap murid atau mahasiswa, dengan menggunakan rumus: $\mathrm{Si}=$ (nilai seorang murid atau mahasiswa dibagi dengan jumlah nilai seluruh murid atau mahasiswa di kelas).

2. Lalu dihitung indeks kompetisi menggunakan rumus " Indeks Haryadi” berikut ini:

$$
H I=\frac{1}{\left[N^{*}\left\{\sum_{i=1}^{N} S_{i}^{2}+\sum_{i=1}^{N} \sum_{j=1}^{N}\left(S_{i}-S_{j}\right)^{2}\right\}\right]} ; i>j
$$

3. Lalu ditentukan tingkat kompetisi sebagai berikut:

a) Indeks Haryadi antara 0,75 sampai dengan 1,00 adalah bersesuaian dengan Tingkat Kompetisi yang Seimbang atau Adil. 
b) Indeks Haryadi antara 0,50 sampai dengan 0,74 adalah bersesuaian dengan Tingkat Kompetisi yang Tidak Seimbang atau kurang Adil.

c) Indeks Haryadi adalah kurang dari 0,50 adalah bersesuaian dengan Tingkat Kompetisi yang Tidak Seimbang atau tidak Adil.

Catatan: Uraian lebih detil terdapat di daftar pustaka sebagai berikut:

\section{Reference (Daftar Pustaka)}

[1] Sigit Haryadi. (2017). Haryadi Index and Its Applications in Science of Law, Sociology, Economics, Statistics, and Telecommunications. Penerbit Elex Media Komputindo. Jakarta. ISBN: 978-602-02-9895-5.

[2] Sigit Haryadi. (2017). Indeks Haryadi dan Penerapan di Ilmu Hukum, Sosiologi, Ekonomi, Statistik, dan Telekomunikasi. Penerbit Elex Media Komputindo, Jakarta. ISBN: 978-602-02-9896-2

[3] Sigit Haryadi. (2017). The Equality Correlation Method. Researchgate. DOI: 10.13140/RG.2.2.10443.80169.

[4] Sigit Haryadi. (2017). Calculation of the Mobile Communication Competition using Haryadi Index. DOI: 10.13140/RG.2.2.15634.25280

[5] Haryadi, S. (2018, February 1). Kalkulator Untuk Mengukur Tingkat Kompetisi di suatu Industri, dengan menggunakan rumus Indeks Haryadi. Retrieved from osf.io/fy $7 z u$

[6] Haryadi, S. (2018, February 7). Statistik Terapan: Pengujian Regulasi \& Kebijakan Telekomunikasi. Retrieved from osf.io/3pkfw

[7] Sigit Haryadi. (2018, February). Applied Statistics for Assessment of the Regulation and Policy: case study in Telecommunication Industry. DOI: 10.13140/RG.2.2.15774.02884

[8] Haryadi, S. (2018, February 1). KALKULATOR untuk membuat Regresi Linier

Tanpa Intersep. Retrieved from osf.io/emvs7

[9] Sigit Haryadi. (2017, December). Calculator for non intercept linear regression. Researchgate. DOI: 10.13140/RG.2.2.15761.94562.

[10] Sigit Haryadi. (2017, December). Calculator for Measurement the Competition Index \& Level. Researchgate. DOI: 10.13140/RG.2.2.23626.26568

[11] Sigit Haryadi. (2017). The. Fairness over Inequality Index: Unfairness is Disaster - a notebook of Sigit Haryadi. Researchgate. DOI: 10.13140/RG.2.2.34379.49449.

[12] Haryadi, S. (2017, November). Probabilitas Statistik Untuk Insinyur. Researchgate. DOI: 10.13140/RG.2.2.14304.58885

[13] Sigit Haryadi. (2017). Harmony in Gradation and its prospects as the Formula of Everything, First edition of posts: December 31, 2017. Researchgate. DOI:

10.13140/RG.2.2.19309.08169

[14] Nie Levin Kusuma Adiatma ; Sigit Haryadi. (2017, October). Comparison of the Haryadi Index with Existing Method in Competition, Equality, Fairness, and Correlation Level Calculation Case Study: Telecommunication Industry. The 11th International Conference on Telecommunication Systems, Services, and Applications, At Lombok, Indonesia.

[15] Sigit Haryadi. (2017). The Non-Intercept Linear Regression Method. Researchgate. DOI: 10.13140/RG.2.2.18721.71522

[16] Sigit Haryadi. (2017, January). Calculation of the Income Equality Levels between Regions using the Haryadi Index. Researchgate. DOI: 10.13140/RG.2.2.36605.77282 
[17] Sigit Haryadi. (2016). Haryadi Index for Competition, Equality and Correlation Evaluation. Penerbit Lantip Safari Media, bandung, Indonesia. ISBN: 978-602-73231-3-2

[18] Sigit Haryadi. (2016). Haryadi Index untuk Evaluasi Kompetisi, Kesetaraan dan Korelasi. Penerbit Lantip Safari Media, bandung, Indonesia. ISBN: 978-602-73231-3-1 [19] Haryadi, S. (2018, February 1). Indeks Haryadi dan Prospeknya Untuk Menjadi Suatu "Formula of Everything (versi 31 Desember 2017). Retrieved from osf.io/zex45 